\title{
Editorial
}

\section{Avaliação das Comunicações Científicas Brasileiras}

Todas as iniciativas para implementar uma melhoria das avaliações nas comunicações científicas são sempre bem vindas. Seja em que área do conhecimento for. Em editoriais anteriores, tentei ressaltar a importância do trabalho dos editores científicos, bem como dos auditores e dos avaliadores pareceristas que atuam nos periódicos, para que tentem garantir uma produção de qualidade.

Muitos são os e-mails que recebemos, com o intuito de tomar-se conhecimento de como se dá o processo interno de avaliações. É preciso esclarecer que trata-se de um processo importante, porém há ainda pouco reconhecimento em tal trabalho. Mesmo havendo espaço para isso nos periódicos, ainda é grande o número de colaboradores que solicitam maiores detalhes sobre os critérios adotados, para que um manuscrito seja aceito.

Nesse sentido, é importante a preocupação dos organismos que assessoram os editores científicos brasileiros, a exemplo da Associação Brasileira de Editores Científicos - ABEC. Esta promove diversos encontros nacionais de Editores Científicos, visando a atualização dos mesmos e modernização das formas de divulgação do material produzido pelos pesquisadores.

É importante que se valorize mais os critérios para avaliação dos próprios periódicos científicos. As formas para suas classificações parece tema inesgotável. Há uma clara necessidade de maior atenção às publicações dos países da América Latina, para que possamos reforçar as parcerias com tais nações, pois comungam com realidades semelhantes a nossa. Outra preocupação parece ser com o futuro das publicações impressas. Será que deve-se garantir a permanência de arquivos em sites que abriguam tais publicações?

Uma outra polêmica, é sobre as exigência de determinadas revistas, quanto à comprovação das avaliações dos manuscritos por um Comitê de Ética independente, em publicações que envolvem seres humanos. É compreensível e bem-vinda. Contudo, há uma diversidade de particularidades com respeito às populações estudadas, além de certa flexibilidade de alguns comitês, tanto em termos das abordagens utilizadas, número de participantes ou procedimentos empregados, inclusive porque são diferentes a cada área do conhecimento.

Desta forma, alguns dos critérios adotados, não podem se ajustar a outros contextos, quando apenas importados, sob o risco de atrapalhar o fluxo de publicações em uma 
Id on Line Revista Multidisciplinar e de Psicologia

Id on Line Multidisciplinary and Psycology Journal

determinada área. Há uma aceitação generalizada, entre editores científicos, quanto a pluralidade de situações, que possam requerer uma consulta à Comissão Editorial ou ao CONEP, quando do atraso nas avaliações solicitadas, de forma a não implicar em atraso no processo editorial.

A uniformização de normas para publicações é uma reivinicação muito antiga, pois tal prática tenderia a acelerar o processo editorial. Os que não são favoráveis a esta política, informam que uma padronização nacional das normas, provocaria interferência na liberdade de seleção dos critérios de cada periódico. Ainda assim, creditamos que vale a pena pensar em algumas vantagens. Um exemplo disso são as dificuldades financeiras quanto a manutenção dos periódicos. A escassez de recursos implica numa redução de mão de obra, como é o caso dos escassos revisores. É possível que a comunidade desconheça a realidade de que, boa parte da revisão dos manuscritos, em geral fica a cargo de uma única pessoa, ou mesmo do próprio editor. Neste sentido, são raras as revistas em que, cada etapa fica a critério de pessoas capacitadas em áreas específicas.

Torna-se fácil, pois, raciocinar que alguns dos problemas de conformidade às normas, não são tão rápidos de resolver, atrasando a checagem e a correção, notadamente o processo editorial como um todo. Os autores bem sabem como perde-se tempo em se adequar as referências, como exigido por cada uma das revistas. Observe-se o grande investimento de tempo e raciocínio para o atendimento a um periódico. Imagine-se quando da submissão aos diversos periódicos disponíveis.

Por último, é importante que se discuta também sobre o papel das agências de fomento, para que abram mais editais favoráveis a divulgação por periódicos científicos, de forma a melhorar as condições de trabalho e, a consequente valorização das comissões que trabalham com avaliação da produção científica.

Pensar e discutir os temas aqui eliciados, ajudará em muito a melhorar a forma como se faz a divulgação da ciência no Brasil. Quem sabe assim, se consega uma maior qualidade nas avaliações, tanto dos periódicos como dos manuscritos que os integrarão.

\section{Gislene Farias de Oliveira, PhD}

Editora

Professora Associada da Universidade Federal do Cariri - UFCA. 